\title{
THE CICADA GENUS Macrosemia Kato, 1925 (Hemiptera: Cicadidae) FROM VIETNAM, WITH THE DESCRIPTION OF A NEW SPECIES AND KEYS TO THE SPECIES
}

\author{
Pham Hong Thai ${ }^{1 *}$, Bui Minh Hong ${ }^{2}$, Jérôme Constant ${ }^{3}$ \\ ${ }^{1}$ Vietnam National Museum of Nature, VAST \\ ${ }^{2}$ Department of Biology, Hanoi National University of Education \\ ${ }^{3}$ Royal Belgian Institute of Natural Sciences, Belgium
}

\begin{abstract}
The taxonomic status of the cicada genus Macrosemia from Vietnam was reviewed. One new species of cicada Macrosemia lamdongensis sp. $\mathrm{n}$. from Lam Dong province in Tay Nguyen area, Vietnam, is described. Two Macrosemia species, M. assamensis (Distant, 1905) and M. divergens (Distant, 1917), are removed from the Vietnam cicada fauna. Information on the distribution of all known species is given. Photos of the adult, illustrations of the male genitalia and a distribution map are provided for the new species. A key to the species of Macrosemia based on characters of the male adults is also given.
\end{abstract}

Keywords: Auchenorrhyncha, Cicadini, Macrosemia, new species, Bidoup-Nui Ba National Park, Vietnam.

Citation: Pham Hong Thai, Bui Minh Hong, Jérôme Constant, 2016. The cicada genus Macrosemia Kato, 1925 (Hemiptera: Cicadidae) from Vietnam, with the description of a new species and keys to the species. Tap chi Sinh hoc, 38(3): 316-323. DOI: 10.15625/0866-7160/v38n3.6632.

*Corresponding author: phamthai@vnmn.vast.vn.

\section{INTRODUCTION}

The cicada genus Macrosemia was erected by Kato (1925b). It belongs to the tribe Cicadini of the subfamily Cicadinae with Platylomia hopponis Kato, 1925 as the type species. In the genus Platylomia, two species, $P$. kareisana (Matsumura, 1907) and P. matsumurai Kato, 1928, were transferred to the genus Macrosemia by Matsumura (1930) [27] and Kato (1931) [20], respectively. Later, Kato (1932) [21] considered his Macrosemia hopponis to be a form of Platylomia kareisana. Two other species were later described in the genus Macrosemia, M. kiangsuensis Kato, 1938, and M. anhweiensis Ouchi, 1938 [32]. The uncertainty about the exact classification of Macrosemia and its closely related genus Platylomia was illustrated by Duffels \& Van der Laan's (1985) [12]. They listed three species in the genus Macrosemia: M. anhweiensis Hua 2000, M. kiangsuensis Hua 2000 (including the variety virescens Liu, 1940), and M. matsumurai (Kato, 1928). Strangely, the type species of Macrosemia, M. hopponis, was listed as a synonym of Platylomia kareisana under Platylomia [REF] and Hayashi (1979) [13] placed this species in Platylomia. Five species: Platylomia divergens (Distant, 1917), $P$. assamensis Distant, 1905, P. diana Distant, 1905, P. saturate (Walker, 1858) and P. pieli Kato, 1938 were transferred to the genus Macrosemia Kato, 1925 by Lee (2008) [24]. Here we describe one new species, Macrosemia lamdongensis sp. n., from Lam Dong Province, Tay Nguyen area, Vietnam.

\section{MATERIALS AND METHODS}

Two males of the new species, Macrosemia lamdongensis, were collected from Da Lat, Lam Dong province, Tay Nguyen area, Vietnam, both type specimens of this new species are deposited in the Museum National d'Histoire Naturelle, Paris, France (MNHN).

Morphological terminology follows that of Moulds (2005) [30]. The male genitalia of the holotype and paratype were examined and photographed using a dissecting microscope (Leica MZ12 5). A distribution map (fig. 1) produced by the software $C F F 2.0$ [1] and photos of the habitus are provided. 


\section{RESULTS AND DISCUSSION}

\section{Taxonomy}

Family Cicadidae Latreille, 1802

Subfamily Cicadinae Latreille, 1802

Tribe Cicadini Latreille, 1802

Genus Macrosemia Kato, 1925

Macrosemia Kato, 1925b: 57.

Type species: Platylomia hopponis Kato, 1925 (Kato 1925a) (Formosa = Taiwan).

Remarks. According to Lee (2008) [24], this genus is distinguishable from its allied genera, especially from Platylomia Stål, 1870, by the following characteristics: body robust and thick; eyes not prominent laterally; head including eyes about as wide as or narrower than base of mesonotum; postclypeus a little prominent anteriorly, shorter than vertex in middorsal length in dorsal view; ventral side of postclypeus, in many species, with distinct fuscous or black central band longitudinally which diverges at anterior end; pronotal collar well developed and broad; mid lateral tooth of pronotal collar produced laterally or posterolaterally, not anterolaterally; male operculum long with comparatively acute apex and swollen at about posterior $2 / 3$; forewing slender with sharp tip, its length longer than $3.2 \times$ width. See also Lee \& Hayashi (2003) [23].

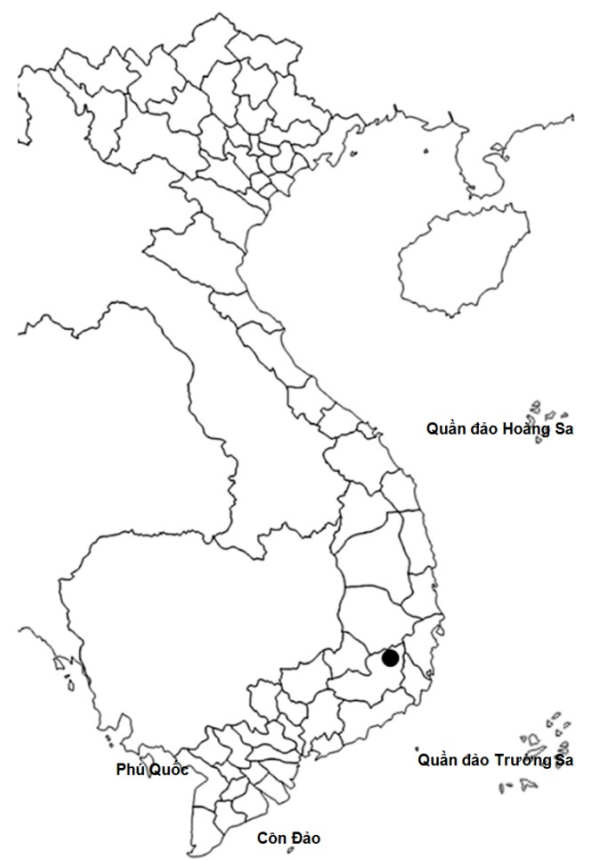

Figure 1. Type locality of Macrosemia lamdongensis sp. $\mathrm{n}$.

Key to the Vietnamese species of the genus Macrosemia

1. Fore wing with widely spread or roundish infuscation on each apical portion of veins RA2, RP, M1, M2, M3, M4, and CuA1

- Fore wing without widely spread or roundish infuscation on each apical portion of veins RA2, $\mathrm{RP}, \mathrm{M} 1, \mathrm{M} 2, \mathrm{M} 3, \mathrm{M} 4$, and CuA1...

.3

2. Tergite 3 with a transverse dense white hair fascia along anterior

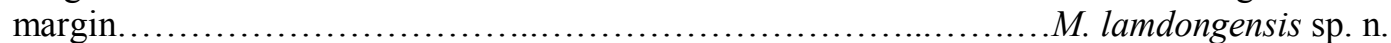

- Tergite 3 without a transverse dense white hair fascia along anterior margin M. saturata

3 Fore and hind wings with basal cell blackish-brown; operculum with a black streak around. M. tonkiniana

- Fore and hind wings without basal cell blackish-brown; operculum without a black streak around.

. .4

4 Male dull ochraceous; operculum reaching sternite VI, entirely ochraceous except extreme margins and apex, posteriorly globosely convex M. diana

- Male greenish ochraceous; operculum large and long reaching centre of sternite VII, widely apart from each other and occupying lateral abdominal areas, strongly sinuate on each side of base and suddenly convex on disk of posterior two-third, narrowed and a little rounded posteriorly.... M. pieli 


\section{Macrosemia lamdongensis sp. $\mathbf{n}$.}

Etymology. The species epithet refers to the locality of origin of the specimens: Lam Dong province in central Vietnam.

Material examined. Holotype $\delta$ : [Vietnam, Lam Dong, Bi Doup massif, Da Lat in bus road to Bi Doup, 12-VI-2008, leg. A. SoulierPerkins] (MNHN).

Paratype (1 $\left.\oint^{\Uparrow}\right)$ : [Vietnam, Lam Dong, Bi Doup massif, Da Lat Hon Giao, 10-VI-2008, light trap, leg. A. Soulier-Perkins] (MNHN).

\section{Description}

Head: head including eyes slightly wider than base of mesonotum; vertex pale green, with large irregular marking at ocellar area, large streak along anterior margin and small streak on/along posterior margin black; frons black with two opalescent markings on posterior margin; ocelli and eyes pale brown; supra-antennal opalescent; gena opalescent with silvery hairs; lorum opalescent with area close to anteclypeus black; postclypeus greenish opalescent with longitudinal streak, transverse groove and margin close to anteclypeus black, pale yellow-brown spot right in middle of apex of posclypeus; anteclypeus yellowish opalescent with two markings brownish-black in middle.

Thorax: pronotum pale green, with surrounding black line, a pair of central longitudinal stripes, broadened both anteriorly and posteriorly, markings along furrows of inner area, and two spots at each posterolateral part of outer dilatation, black; pronotal collar pale green, margin and marking on lateral part of pronotal collar black, with dentate projection but not acute, apex brown-black; mesonotum pale green, with five black broad fasciae, median fascia extending from anterior margin of mesonotum to cruciform elevation, and ending in black triangle on cruciform elevation, posterior half 1.5-3 times as wide as anterior part, paramedian suture extending to just beyond half-length of mesonotum, 1.5-5 times as wide as anterior part of median fascia, and about as broad as or somewhat broader than distance between paramedian and median fasciae, pair of round black spots in front of anterior angles of cruciform elevation, lateral fasciae continuous from anterior to posterior margin of mesonotum and about as broad as distance between lateral and paramedian fasciae; two pairs of small black triangles at anterior mesonotal margin between paramedian and lateral fasciae, cruciform elevation greenish opalescent with margin of posterior angles black, wing groove black; thorax greenish opalescent in ventral view, with episterna 2, 3 black.

Wings: fore and hind wings hyaline, fore wing venation pale yellow-brown basally and brown-black apically; fore wings slightly tinged and spotted with infuscations on $\mathrm{r}, \mathrm{r}-\mathrm{m}, \mathrm{m}-\mathrm{cu}$, and $\mathrm{CuA} 2$, on RA, RP, M1, M2, M3, M4, $\mathrm{CuA} 1, \mathrm{CuA} 2$, on $\mathrm{M} 3+4, \mathrm{CuP}+1 \mathrm{~A}$, and on node, basal cell and clavus pale brown; hind wings with infuscations on basal M2 and $\mathrm{M} 3+4$.

Legs: all legs pale yellow-brown with markings as follows: femurs of all legs with longitudinal fasciae brownish-black, coxae greenish opalescent, all legs with black markings at base, tibiae of fore and middle legs with brownish-black longitudinal fasciae, tarsi of fore and middle legs brownish-black, tibial spur and pretarsal claw of hind leg brownishblack; primary spine of pale brown, secondary spine brownish-black at apex

Abdomen: longer than distance from head to cruciform elevation, black in dorsal view, tergite 3 with a transverse fascia of dense white hairs along the anterior margin, with the fascia enlarged at the lateral margins; tergites 4-6 with edges of lateral margins pale brown; timbal cover black, distinctly covering timbal; pale yellow-brown in ventral view, posterior margin of sternite II and anterior margin of sternite III black, posterior margin of sternite IV-VI and sternite VII dark brown, area close to posterior margin of sternite VII with brownish black Xshaped marking, apex of sternites VIII brownish black.

Operculum: elongate, fairly broad, and reaching posterior margin of segment 7 . Inner margin evenly convex. Lateral margin weakly convex at base, concave at one third of its length from base, and weakly convex in apical 
two thirds. Operculum pale greenish, with one fifth of length from base black, rim along operculum margin pale yellow-brown except basal part of outer margin black.

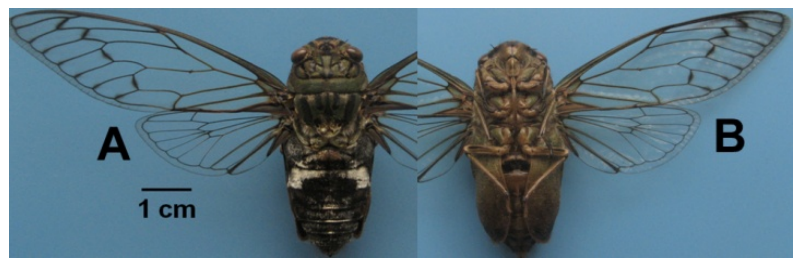

Figure 2. Macrosemia lamdongensis sp. nov.

A. Dorsal view of male; B. Ventral view of male.

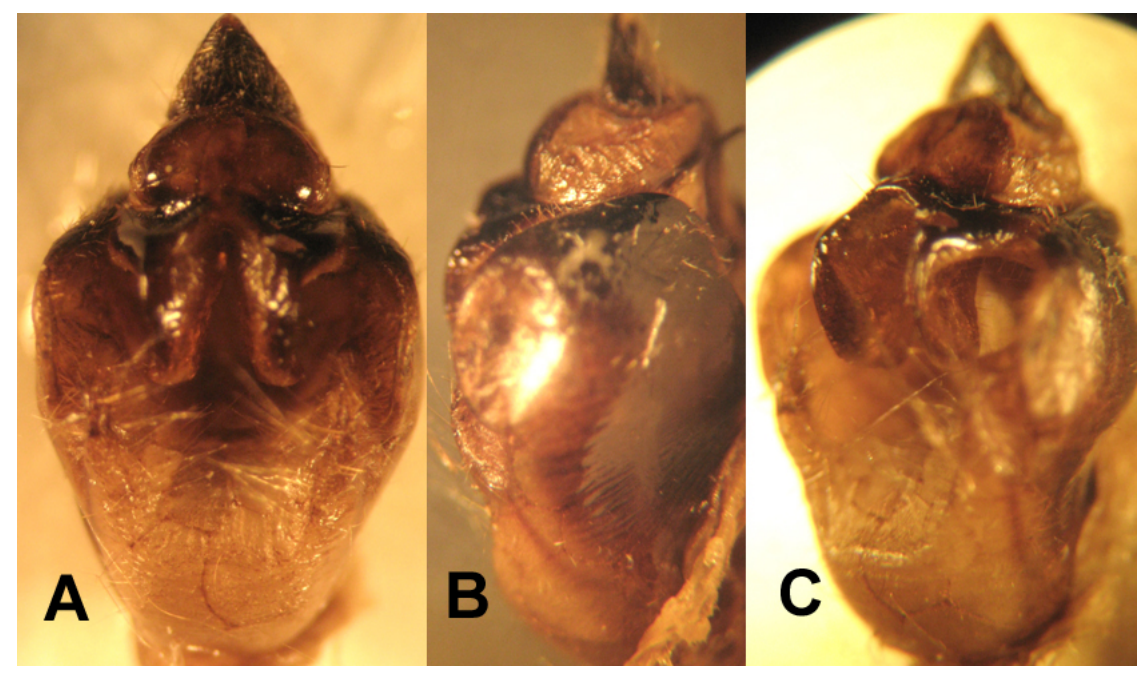

Figure 3. Macrosemia lamdongensis sp. nov.

A. Male genitalia in ventral view; B. Male genitalia in lateroventral view; C. Male genitalia in lateral view.

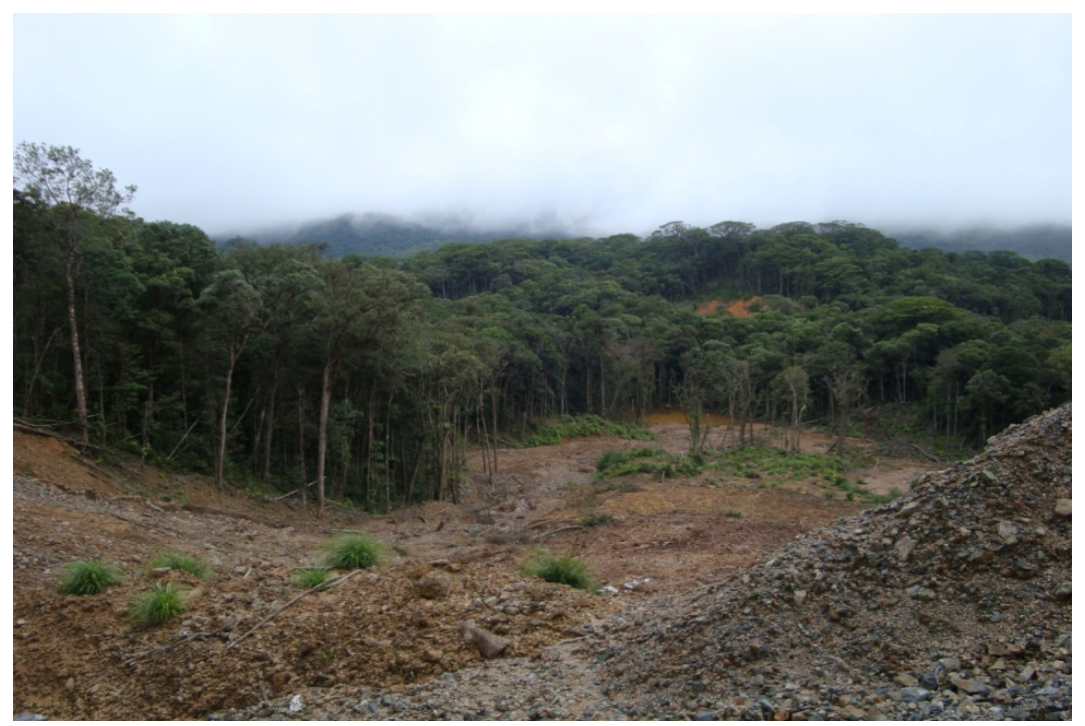

Figure 4. The habitat of Macrosemia lamdongensis sp. nov. the collecting locality 
Genitalia $\widehat{\delta}^{\lambda}$ : pygofer oval in ventral view, lateral margin at one second parallel in ventral view, basal lobe of pygofer with parallel ridges, apical distinct prominent brown-black marking with dense hair, upper lobe of pygofer apically brown-black, rounded without protrusion; uncus bifurcate, pale brown, uncus lobes with medial margin weakly concave, brownish-black at base, each uncus lobe on ventral (outer) surface with ridge.

Measurements in mm, (2 males): body length male: 42.7 (42.6-42.8); fore wing length male: 54.2 (54.0-54.4); head width male: 14.3 (14.0-14.5); pronotum width male: 15.5 (15.215.8).

Distribution: Vietnam (Lam Dong province). Macrosemia diana (Distant, 1905)

Platylomia diana Distant, 1905b: 201 [Type location: Se-Tchouen]; Distant, 1917b: 319; Metcalf, 1963b: 616; Lee, 2008: 16; Pham \& Yang, 2009: 14.

Material examined. No specimens were examined.

Distribution. Vietnam, China (Sichuan and Fujian).

\section{Macrosemia saturata (Walker, 1858)}

Dundubia saturata Walker, 1858b: 6 [Type location: North India (Sikkim Himalaya)].

Platylomia saturata: Distant, 1917b: 319; Moulton, 1923: 101, 167; Metcalf, 1963b: 624; Lee, 2008a: 16; Pham \& Yang, 2009: 14.

Material examined. No specimens were examined.

Distribution. Vietnam, Malay Peninsula, Indonesia (Java), Bangladesh, Bhutan, Nepal, India.

\section{Macrosemia pieli (Kato, 1938)}

Platylomia pieli Kato, 1938: 11 [Type location: T'ienmu Shan, China]; Chou et al., 1997: 252; Lee, 2008: 16; Pham \& Yang, 2009: 14.

Material examined. No specimens were examined.

Distribution. Vietnam, China (Sichuan, Hunan, Jiangxi, Zhejiang, Anhui and Fujian).

\section{Macrosemia tonkiniana (Jacobi, 1905)}

Cosmopsaltria tonkiniana Jacobi, 1905: 429 [Type location: Chiem-hoa, Tonking]; Distant, 1906: 56; Distant, 1912: 45; Distant, 1917a: 101; Schmidt, 1932: 126; Kato, 1934: 154; Metcalf, 1963a: 555.

Platylomia tonkiniana: Chou et al., 1997: 258.

Macrosemia tonkiniana: Boulard, 2003a: 266; Boulard, 2003b: 104; Sanborn et al., 2007: 21; Lee, 2008: 16; Pham \& Yang, 2009: 15.

Materials examined. Son La: $14 \hat{\jmath}$, Moc Chau, 1,000-1,100 m, light trap, 28.viii.1992; Lao Cai: 1ठ, Sa Pa, 1,200 m, 20.vii.2001, light trap; 1 ${ }^{\lambda}$, same locality, 9.x.2004, light trap; Yen Bai: 1ð̂, Yen Bai city, 11.viii.2004, at light, coll. Pham Hong Thai; Nghe An: 10, Binh Chuan, Con Cuong, 5.viii.2005; 1ठ, $\mathrm{Pu}$ Huong, Quy Hop, light trap, 14.vii.2004; 2へ, headquarters of $\mathrm{Pu}$ Mat NP, 250m, light trap, 26.vii.2004; 10, same locality, light trap, 10.viii.2002; 2र, same locality, light trap, 25.vii.2004, coll. Dang Duc Khuong and Le Xuan Hue; 1ठ, same locality, 23.vii.2004.

Distribution. Vietnam (Son La, Lao Cai, Yen Bai, Nghe An,), China (Yunnan and Hainan), Laos, Thailand, Myanmar, and India.

\section{DISCUSSION}

The new species differs from all species in the genus Macrosemia in Vietnam (exclude in the species $M$. saturata) in the markings of fore wing that widely spread or roundish infuscation on each apical portion of veins RA2, RP, M1, $\mathrm{M} 2, \mathrm{M} 3, \mathrm{M} 4$, and $\mathrm{CuA} 1$, forming a series along subapical margin of fore wing, while the rest has fore wing without widely spread or roundish infuscation on each apical portion of veins RA2, RP, M1, M2, M3, M4, and CuA1, forming a series along subapical margin of fore wing.

The new species Macrosemia lamdongensis is distinguishable from $M$. saturata by the markings on the third abdominal tergite, with a transverse fascia densely covered with white hair along anterior margin in $M$. lamdongensis and without such fascia along anterior margin in M. saturata. 
The specimens were collected in a humid forest in a very good state, with big trees but of an easy access since a road was freshly cut into it in order to get trough the massif of Bi Doup. Typical biotope for the species is seen in figure 4.

Species to be removed from the Macrosemia species list of Vietnam

Macrosemia assamensis (Distant, 1905)

Platylomia assamensis Distant, 1905a: 65 [TL: Assam]; Distant, 1906: 60; Chou et al., 1997: 258; Lee, 2008: 16; Pham \& Yang, 2009: 14. India.

Distribution. China (Yunnan), Thailand,

Remarks. Chou et al., 1997 recorded the species from Vietnam by mistake, based on Distant (1905a), who actually recorded this species in Assam only. Lee (2008a) and Pham \& Yang (2009) repeated Chou et al.'s error.

Macrosemia divergens (Distant, 1917)

Cosmopsaltria divergens Distant, 1917b: 319, 321 [Type location: Laos; Luang Piahang]; Metcalf, 1963a: 547; Lee, 2008: 16; Pham \& Yang, 2009: 14.

Distribution. Laos.

Remarks. Distant (1917) described this species from Luang Piahang (Luang Prabang) in Laos. Later, Metcalf (1963) recorded this species in "Indochina". Lee (2008) [24] mentioned $M$. divergens from Vietnam and Laos based on Distant (1917) [11] and Metcalf (1963) [a]. Pham \& Yang (2009) [33] also erroneously recorded this species in Vietnam again. Actually, the term "Indochina" covers three countries: Cambodia, Laos, and Vietnam. After careful checking of the references we noticed that no specimen of this species was ever reported from Vietnam. The species is here removed from the fauna of Vietnam.

Acknowledgments: We thank Dr. Hans Duffels (Naturalis Biodiversity Center, Leiden) and an anonymous reviewer for their critical readings and valuable comments in improving the contents of the paper. We are grateful to Dr. Adeline Soulier-Perkins (The Museum National
d'Histoire Naturelle, Paris) for providing photographs of the habitat of Macrosemia lamdongensis. The first and third authors' collection trips were supported through a grant issued by the capacity building Programme of the Belgian Global Taxonomic Initiative National Focal Point that runs with financial support from the Belgian Directorate-General for Development Cooperation. The present study was partially supported by National Foundation for Science and Technology Development (NAFOSTED-106.12-2012.63), Vietnam, the bilateral cooperation (VAST.HTQT.BELARUS.03/15/16), TWAS Research Grants Programme (13-098 RG/BIO/AS_G; UNESCO FR: 3240277734). Special thanks go to IdeaWild for the donation of equipments to the first author for this study. This study would not have been possible without the help of Dr. Thierry Bourgoin, Dr. Jérôme Sueur and Dr. Adeline Soulier-Perkins (Museum National d'Histoire Naturelle, Paris) kindly allowed me to access to MNHN collection, and the support from The Museum National d'Histoire Naturelle, Paris.

\section{REFERENCES}

1. Barbier Y., Rasmont, P., 2000. Carto FaunaFlora 2.0. Guide d'utilisation. Université de Mons Hainaut, Mons, Belgique, 59 pp.

2. Beuk P. L. Th., 2002. Cicadas spreading by island or by spreading the wings. Historic biogeography of the dundubiine cicadas of the Southeast Asian continent and archipelagos. Thesis, Universiteit van Amsterdam, 323pp.

3. Boulard M., 2003a. Statut taxonomique et acoustique de quatre cigales thaillandaises, dont deux restées inédites jusqu'ici (Rhynchota, Cicadoidea, Cicadidae). Nouvelle Revue d'Entomologie, 20(3): 259279.

4. Boulard M., 2003b. Éthologie sonore et statut acoustique de quelques cigales thaillandaises, incluant la description de deux espèces nouvelles (Hemiptera: Auchenorhyncha, Cicadoidea, Cicadidae). Annales de la Société entomologique de France, 39(2): 97-119. 
5. Chou I., Lei Z., Li L., Lu X., Yao W., 1997. The Cicadidae of China (Homoptera: Cicadoidea). Ilustrataj Insectfaunoj, 2. Tianze Eldoneio, Hong Kong, 10+380+5 pp., 4+16 pls. (In Chinese with English summary).

6. Distant W. L., 1905. Rhynchotal notes. XXIX. The Annals and Magazine of Natural History, 7: 15, 58-70.

7. Distant W. L., 1905. Additions to a knowledge of the homopterous family Cicadidae. Transactions of the Royal Entomological Society of London, 191-202.

8. Distant W. L., 1906. A synonymic catalogue of Homoptera, part 1. Cicadidae. British Museum (Nat. Hist.), London, 207 pp.

9. Distant W. L., 1912. Homoptera, Fam. Cicadidae, Subfam. Cicadinae. In: Genera insectorum, 142. pp. 1-64, pls. 1-7.

10. Distant W. L., 1917. The Homoptera of Indo-China. The Annals and Magazine of Natural History, 19(8): 100-104.

11. Distant W. L., 1917. The Homoptera of Indo-China. The Annals and Magazine of Natural History, 20(8): 319-325.

12. Duffels J. P., Van der Laan P. A., 1985. Catalogue of the Cicadoidea (Homoptera, Auchenorhyncha) 1956-1980. Series Entomologica, 34. Dr. W. Junk Publishers, Dordrecht, xiv +414 pp.

13. Hayashi M., 1979. A list of Taiwanese Cicadidae collected by Prof. K. Kojima and Mr. S. Nakamura (Homoptera). Rostria 30: 259-262. (In Japanese with English summary).

14. Jacobi A., 1905. Zur Kenntnis der Cicadenfauna von Tonking. Zoologische Jahrbücher, 21: 425-446, pl. 21.

15. Kato, M., 1932, Monograph of Cicadidae. Sanseido, Tokyo, 450 pp., 32 pls. (In Japanese).

16. Kato M., 1934, Notes on Chinese Cicadidae. The Entomological World, Tokyo, 2: 144161, pls. 61-62. (In Japanese).

17. Kato M., 1938. Studies on Chinese Cicadidae in Musée Heude collection.
Bulletin of the Cicadidae Museum, 2: 1-28. (In Japanese with English resume).

18. Kato M., 1925. Japanese Cicadidae, with descriptions of new species. Transactions of the Natural History Society of Formosa, 15: 1-46, 1 pl. (in Japanese).

19. Kato M., 1925. The Japanese Cicadidae, with descriptions of some new species and genera. Transactions of the Natural History Society of Formosa, 15: 55-76, pls. 1-2. (In Japanese with English descriptions).

20. Kato M., 1931. Semi, part 3. Transactions. Natural History Society of Formosa. Taihoku. 21: 217-221.

21. Kato M., 1932. Monograph of Cicadidae. Sanseido, Tokyo, 450 pp., 32 pls. (In Japanese).

22. Kato M., 1938. Studies on Chinese Cicadidae in Musée Heude collection. Bulletin of the Cicadidae Museum, 2: 1-28. (In Japanese with English resume).

23. Lee Y. J., Hayashi M., 2003. Taxonomic review of Cicadidae (Hemiptera, Auchenorrhyncha) from Taiwan, part 1. Platypluerini, Tibicenini, Polyneurini, and Dundubiini (Dundubiina), Insecta Koreana, 20: 149-185.

24. Lee Y. J., 2008. A checklist of Cicadidae (Insecta: Hemiptera) from Vietnam, with some taxonomic remarks. Zootaxa, 1787: 127.

25. Liu G. K. C., 1940. New oriental Cicadidae in the Museum of Comparative Zoölogy. Bulletin of the Museum of Comparative Zoölogy at Harvard College, 87: 73-117, 7 pls.

26. Matsumura S., 1907. Die Cicadinen Japans. Annotationes zoologicae Japonenses, 6(1): 83-116.

27. Matsumura, S., 1930. Rhynchota. The illustrated thousand insects of Japan. 1: 1198.

28. Metcalf Z. P., 1963a. General catalogue of the Homoptera, fascicle VIII, Cicadoidea, part 1. Cicadidae. section I. Tibiceninae. North Carolina State College, Raleigh, pp. $1-585$. 
29. Metcalf Z. P., 1963b. General catalogue of the Homoptera, fascicle VIII, Cicadoidea, part 1. Cicadidae. section II. Gaeninae and Cicadinae. North Carolina State College, Raleigh, pp. 587-919.

30. Moulds M. S., 2005. An appraisal of the higher classification of cicadas (Hemiptera: Cicadoidea) with special reference to the Australian fauna. Records of the Australian Museum, 57: 375-446.

31. Moulds M. S., 2012. A review of the genera of Australian cicadas (Hemiptera: Cicadoidea). Zootaxa, 3287: 1-262.
32. Ouchi Y., 1938. Contributiones ad cognitionem insectrum Asiae Orientalis. The Journal of the Shanghai Science Institute, (Section. III), 4: 75-111.

33. Pham H. T., Yang J. T., 2009. A contribution to the Cicadidae fauna of Vietnam (Hemiptera: Auchenorrhyncha), with one new species and twenty new records. Zootaxa, 2249: 1-19.

34. Schmidt E., 1932. Verzeichnis der cicaden des chinesischen reiches. Peking Natural History Bulletin, 7(2): 117-133.

\title{
GIỐNG VE SẦU Macrosemia Kato, 1925 (Hemiptera: Cicadidae) Ở VIẸT NAM, VỚI MÔ TẢ MỘT LOÀI MỚI VÀ KHÓA ĐỊNH LOẠI ĐẾN LOÀI
}

\author{
Phạm Hồng Thái ${ }^{1}$, Bùi Minh Hồng ${ }^{2}$, Jérôme Constant ${ }^{3}$ \\ ${ }^{1}$ Bảo tàng Thiên nhiên Việt Nam, Viện Hàn lâm KH \& CN Việt Nam \\ ${ }^{2}$ Khoa Sinh học, Trường Đại học Sư phạm Hà Nội \\ ${ }^{3}$ Royal Belgian Institute of Natural Sciences, Belgium
}

\section{TÓM TẮT}

Vị trí phân loại của các loài thuộc giống ve sầu Macrosemia ở Việt Nam được xem xét. Một loài mới thuộc giống này, Macrosemia lamdongensis sp. n. được mô tả. Loài mới này khác với tất cả các loài thuộc giống Macrosemia (trừ loài Macrosemia saturate) bởi các vệt đốm trên cánh trước. Loài mới cũng được phân biệt với loài $M$. saturata bởi vệt lông tơ màu trắng trên đốt bụng thứ 3. Mẫu vật của loài này thu được ở Vườn quốc gia Bidoup-Núi Bà, tỉnh Lâm Đồng, Việt Nam. Trưởng thành và cấu tạo bộ phận sinh dục của con đực được minh họa. Hai loài, M. assamensis (Distant, 1905) và M. divergens (Distant, 1917), không thuộc khu hệ ve sầu của Việt Nam. Bài báo đưa ra khoá định loại cho 5 loài đã biết ở Việt Nam: Macrosemia lamdongensis sp. n., M. diana (Distant, 1905), M. saturata (Walker, 1858), M. pieli (Kato, 1938) và M. tonkiniana (Jacobi, 1905) dựa vào con trưởng thành đực. Bài báo còn cung cấp thông tin về phân bố của tất cả các loài hiện đã biết ở Việt Nam.

Tù khóa: Auchenorrhyncha, Cicadini, hình thái học, loài mới, phân loại học, vườn quốc gia Bidoup-Núi Bà.

Received 30 July 2015, accepted 20 September 2016 